Article

\title{
Japan's New Left and New Wave. An Ideology's Perspective as an Alternative to That of National Cinema
}

\author{
Ferran de Vargas $(\mathbb{D}$ \\ Department of Translation, Interpretation and East Asian Studies, Universitat Autònoma de Barcelona, \\ 08193 Bellaterra, Barcelona, Spain; ferran.devargas@uab.cat
}

Received: 17 October 2018; Accepted: 18 December 2018; Published: 20 December 2018

\begin{abstract}
Starting from the perspective that national cinema is not a neutral concept, but rather a film expression with ideological implications, in this article I will argue that what should be analysed in films is not what connects them to certain nations, but with certain ideologies. Rather than claiming the national nature of a film, it is more accurate to identify for instance elements of a national ideology underlying the film. It can be more enriching to analyse different film trends that are based on their connections with different ideologies, thus stressing their political nature, rather than highlighting cultural or geographical features in order to determine the supposedly natural outline of national cinemas. From this point of view, I consider the Japanese New Wave cinema of the 1960s and early 1970s to be a reflection of Japan's coetaneous New Left ideology. In order to illustrate this political reading of the Japanese New Wave, I focus on the analysis of a paradigmatic film: Eros + Massacre (Erosu purasu Gyakusatsu 1969), directed by Yoshida Kijū.
\end{abstract}

Keywords: film studies; ideological analysis; ideology; Japanese cinema; nation; national cinema; New Left; New Wave; Nuberu Bagu; Yoshida Kiju

\section{Introduction}

Considering that Japan's cinema has occupied in Europe and the United States a discursive position of otherness more than any other Asian cinema (Needham 2006, p. 8), it can be taken as an illustrative case of the efforts that are made by some scholars to construct an idea of national cinema and of the implications of this construction. In this article, I start with the premise that 'national cinema' is not a neutral concept, but a kind of film expression with ideological implications. I will argue that what should be analysed in films is not what connects them to certain nations, but with certain ideologies.

Authors such as Higson (2002) have criticized the 'limiting imagination' of national cinema by focusing especially on the transnationality of film production or reception and the impossibility of unambiguously determining the specific culture of any particular nation. Although this is a first step towards questioning the paradigm of national cinema, I do not only aim to highlight the limiting nature of the model, but also its non-validity. Beyond the transnational and cultural factors, I consider that what allows us to question the validity of the model of national cinema is the ideological and subjective basis that defines the national reality in its fitting with cinema. From this point of view, rather than claiming the national nature of a film, it is more accurate to identify for instance elements of a national ideology underlying the film. It can be more enriching to analyse different film trends based on their connections with different ideologies, thus stressing their political nature, than highlighting cultural or geographical features in order to determine the supposedly natural outline of national cinemas.

I consider that all artistic expression is linked to a certain ideology (or ideologies), and in order to illustrate this ideological perspective in contrast to the national one, I aim to explore the hypothesis 
that the Japanese New Wave cinema of the 1960s and early 1970s is mainly a reflection of Japan's coetaneous New Left ideology. Even though the works in English of authors such as Desser (1988), Standish (2011), and Furuhata (2013), have addressed the Japanese New Wave thoroughly, taking into account the immediate socio-political context, they are not based on an exhaustive analysis of the New Left's ideology underlying the films that make up this film trend, but they are more focused on other important aspects of the cinematographic phenomenon. As Kellner (1993, p. 55) points out, addressing film politically "means not only reading film in a socio-political context, but seeing how the internal constituents of a film also either encode relations of power and domination, serving to advance the interests of dominant groups at the expense of others, or oppose hegemonic ideologies, institutions, and practices". It is not just a matter of linking a film phenomenon with a general socio-political context, but of linking it with the ideology of a particular socio-political agent. In this case, I think it is important to explore in English the path that consists of starting with a systematic definition of Japan's New Left ideology from which to find correlative film features. In this way, the elements of the film discourse that work as means in the social confrontation of powers can be decoded.

In order to illustrate this political reading of the Japanese New Wave, at the end of the article I focus on the concrete analysis of a paradigmatic film: Eros + Massacre (Erosu purasu Gyakusatsu 1969), directed by Yoshida Kijū. Although authors such as McDonald (1983), Desser (1988), Yomota [2004] (2010), Standish (2011), and Briciu (2012), have addressed this film in depth, they have not done so based on a political reading like that proposed by Kellner. Yomota [2004] (2010, p. 51) states that "in the period between 1968 and 1972 the political vanguard and artistic experiment joined hands and together created an expression of these exalted times", 1 and he admits that "in order to understand the awareness embedded in this film, it is vital to grasp the epistemological context of the era in which it was planned and made". Based on this lack of groundwork Yomota observes, I aim to develop an analysis of Eros + Massacre in the light of its ideological reality.

\section{Nation, National Cinema and the Ideology of Cinema: The Case of Japan}

Higson (2002) questions the usefulness of the notion of national cinema because it is only possible to establish what does not define the concept, not what defines it. Indeed, if we try to define Japanese national cinema, we cannot do it based on the production side due to the existence of cases such as Ernesto (Erunesuto 2017), a film co-produced by Japan and Cuba, directed by a Japanese filmmaker (Sakamoto Junji), starring a Japanese actor (Odagiri Jō) talking in Spanish (with a strong Japanese accent even though he plays the role of a Bolivian), set in Cuba, and whose main theme is Cuban history. Nor can we define it based on the reception side since there are films produced in a nation with greater success abroad.

The impossibility of defining the 'national' aspect of a cinema through production or reception due to transnational cases means that some authors end up trying to focus on the content of films, or even to set some cultural features that are intrinsic to a nation in order to link them to certain films made in that very national space. For instance, according to Hill, what allows us to talk in terms of national cinema within the context of Britain is the capability of "registering the lived complexities of British 'national' life" (Hill 1996, p. 16) and of working with or addressing 'nationally' specific materials (Hill 1992, p. 16). On the other hand, according to Ramlochand (2006, pp. 21-22), national cinema is the whole set of films made in a particular spatial context, but while he admits that it cannot

1 Although most of the filmmakers who made up the Japanese New Wave did not consider themselves to be members of a movement, there are shared objective film features that allow us to speak at least of a cinematographic trend. Desser (1988, pp. 4-5) talks about the Japanese New Wave in terms of an 'avant-garde movement' because, according to him, it was a set of films produced with a particular disjunctive form compared to previous filmic norms, with a political stance and with a concrete end. Also Adler (2009, p. 14) states: "That the term New Wave has continued to be used to this day as a generic designation for a cluster of innovative Japanese directors is not problematic per se, on the condition that the simplistic equivalence with the innovations of the French cinema of the late 1950s and early 1960s that the Japanese Nüberu Bāgu was initially designed to convey be nuanced". 
be defined in terms of a singular mood, he paradoxically claims that the best candidates to define Japanese national cinema are those films that reflect the sociocultural and religio-philosophical legacy of Japan; a legacy that is characterized according to him by a non-logocentric and non-conclusive view, a mood of sadness and resignation, and a strong sense of impermanence (ibid., pp. 114-15). However, it should be noted that these kinds of exercises are too arbitrary and can be essentialist.

In this regard, can we consider Ernesto to be a part of Cuban national cinema due to its nationally specific theme, in spite of the strong Japanese involvement in its production? Moreover, if we take into account that a film such as Story of the Loyal 47 Ronin (Genroku Chushingura 1941-42), considered by Burch (1979) as an example of paradigmatic Japanese cinema, was one of the biggest commercial failures of Mizoguchi Kenji's entire career as a filmmaker, can we still consider it a component of Japanese national cinema? What is the nation but the people that make it up and thus its audiences?

Raine's (2002, pp. 60-65) criticism of Stephen Prince's study on the cinema of Kurosawa is very illustrative of the arbitrariness involved in determining certain characteristics intrinsic to a nation and national cinema. According to Raine, in order to conclude that Kurosawa's struggler worldview was fundamentally marked by Japanese indigenous traditions, Prince highlights the influence on his films of alleged bushido values that were received from his military father, and of the legacy of Japan's rebellious agrarian monks and peasants as well as legendary samurai personalities. Nevertheless, Raine points out that the Japanese military was one of the most modern and western considered parts of the nation during the Taisho period (1912-25), that some of the values that Prince associates with bushido could be also associated with Prussian transnational influences, and that modern left-wing movements could have had a significant influence on Kurosawa's struggler worldview.

These kinds of ambivalences, present to a greater or lesser extent in any cultural production, make it too difficult to define national cinema. Obviously, the term 'national' comes from that of 'nation', so it seems logical to think that the first step to find a definition of 'national cinema' is to figure out what a nation is. Nevertheless, it is the very definition of 'nation' what paradoxically causes the impossibility of establishing the meaning of 'national cinema', and not only the problem of transnational production/reception or national essentialisms. Therefore, what I propose here is not only a questioning of the usefulness of the national cinema model but also of its validity. One of the authors who has achieved the greatest consensus in theorizing the concept of nation, Gellner (Gellner 1988, p. 7), states the following:

Two men are of the same nation if and only if they recognize each other as belonging to the same nation. [ ... ] Nations are the artefacts of men's convictions and loyalties and solidarities. A mere category of persons (say, occupants of a given territory, or speakers of a given language, for example) becomes a nation if and when the members of the category firmly recognize certain mutual rights and duties to each other in virtue of their shared membership of it.

The fundamental idea of this conceptualization is that what determines the existence of a nation is not a spatial component or some common characteristics that a group of people shares, but the fact that these people subjectively decide to use that space and those characteristics in order to constitute themselves as a nation; namely, a set of people who, due to whatever historical circumstances, believe they have the right to sovereignly govern themselves in a specific territory.

Thus, a nation is something invented, unlike, for instance, a class, which is the product of our objective position in the relations of production. However, it does not mean that the nation is not real. It is important to highlight the nuance made by Anderson (Anderson 2006, p. 6) when criticizing the standpoint that "assimilates 'invention' to 'fabrication' and 'fallacy', rather than to 'imagining' and 'creation'". The fact that a nation is an imagined community does not mean that it is invented in an exclusively subjective, conscious, manipulative, and unilateral way; it is a complex and changing creation that is based on some objective elements, and in that many agents participate with different degrees of power and different national perceptions, often in a contradictory and more or less unconscious way. 
If we rely on this conception of what a nation is, then we realize that the importance of the subjective factor makes it impossible to accurately determine the 'national' aspect of cinema. Because one can ask a person or a set of people whether they consider themselves to be from a particular nation, but one cannot ask a film or a set of films, since films are objects and not subjects. The cases of films made within the margins of a stateless nation and focused to some extent on specific materials of that nation illustrate very well the impossibility of defining the 'national' aspect of cinema. For instance, if we rely solely on the legal nationality (that is to say, the state) of a Catalan film, we could affirm that it is Spanish cinema, but we cannot affirm that it is objectively Spanish national cinema or Catalan national cinema. What we can do is determine whether the film contains a Spanish or Catalan national ideology. It is this very ambiguity of the concept of national cinema that probably leads to D'Lugo (1991, p. 131) speaking in terms of "something like a national cinema" when talking about a set of Catalan films, establishing a kind of conceptual hierarchy that reflects the existing material hierarchy between nations.

In any case, although we cannot satisfactorily define what the concept of national cinema implies, what we can do is identify and analyse national ideologies underlying several films, always taking into account the context of those films. National ideologies are based on claiming the people as a nation, and explain reality based on (or giving significant importance to) the division and relationship between nations. These kinds of ideologies can be used at the same time to construct, preserve, and strengthen certain nations (and more indirectly, to weaken others, or to counteract other kinds of divisions, such as class or gender). For instance, nationalism is a kind of national ideology that can be aimed at obtaining a state for a stateless nation, defending the state it already has, fostering the internal unity of the nation, protecting it against external or internal powers, or boosting its economy through the cultural label of its films in the global market. However, within nationalism there are several variations, such as for instance what Ko (2010) calls 'cosmetic multiculturalism' when talking about some Japanese films, a kind of ideology that welcomes cultures other than the dominant one, but only appreciates them as depoliticized 'objects' of consumption. Sovereignism, however, is another national ideology that is different from nationalism and seeks to support the sovereignty of a nation, the right of its people to decide if they govern themselves in one way or another, with or without a state, and with more or fewer external influences.

In this sense, the work of Davis (1996) about the sense of Japaneseness projected by many pre-war films made in Japan is very illustrative, because he interprets it not as a sign that serves to define the objective outline of Japanese national cinema, but rather as a film aesthetic that served the interests of Japanese nationalism. He calls this national aesthetic 'monumental style', and points out that it is characterized by a canonization of Japanese history, a sacralization of selected Japanese culture and traditions, an emphasis on indigenous art forms and design, long takes and long shots, slow camera movements and narrative, ceremonial acting and settings, and an epic and reverential tone that marks the themes. These 'monuments' to Japaneseness in the form of films operated mainly as tools for the mass mobilization in support of the colonialist war in Asia, and against the cultural influence of the west. The films that were made by Mizoguchi during World War II, such as, for example, the aforementioned Story of the Loyal 47 Ronin, can be considered as belonging to this kind of aesthetics.

However, Gerow (2009, p. 187) points out that Davis' analysis of the Japaneseness of pre-war films does not take into account important elements that are beyond the film's textuality, such as the mass consciousness and culture reflected in the audiences, which a lot of box-office failures of monumental style films reveal, or the debates and disagreements during the war about what Japaneseness is and what represents the Japanese nation; films of monumental style, in fact, were cited by some critics of the time as examples of what should not represent the nation. Nevertheless, Gerow's criticism should not lead us to discard the fundamentally ideological nature of national cinema. Instead, it should lead us to conclude that there is not a single national ideology and thus a single notion of national cinema for each nation in each historical moment, nor a univocal and strictly conscious aesthetic process of manipulation to serve the interests of a certain regime, but rather a dynamic relationship of powers among multiple agents with different perceptions and grades of consciousness about what is national. 
If questions such as "what film characteristics make a cinema national" or "to which national cinema do particular film or film features belong" are not as useful to gain an objective understanding of cinema as to subjectively shape certain national ideologies, replacing them with questions such as "what ideology (or ideologies) are certain films or film features aligned with" or "the interests of which social group(s) are promoted by certain films or film characteristics" can lead to a more fruitful epistemological field.

While determining the outline of a national cinema implies creating a national ideology, determining the ideologies underlying films mainly implies generating a political view of cinema: it is about understanding how different social groups see the world, how they seek to transform it or prevent it from transforming, how they are placed in the network of power relations that constitutes every society, and how all of this is reflected in films.

An ideology can be understood as the dynamic set of explicit expressions belonging to a doctrine (theories, novels, manifestos, speeches, films, paintings, etc.), of socializing or ritual practices and institutions, and of experiential and subjective perceptions of reality, which are linked to a greater or lesser extent to the interests of specific social agents in a socially significant power relationship or struggle. Part of this definition is based on the three vectors Žižek (1994) distinguishes in ideology. However, my definition is based more on a sociological tradition than on an epistemological one, since it is concerned about the role of ideologies in society instead of trying to discern whether an ideology is more or less adjusted to an objective reality. Moreover, here, ideology is not understood as something related only to social classes, and even less to the ruling class only, but more broadly to social agents.

In order to analyse any explicit expression belonging to a doctrine (in this case, films or film features), first we should identify the ideologies of the main social agents that make up the power network of the historically specific society from which the very explicit expression appears, and analyse at least their general characteristics. Subsequently, we should look for lines of convergence between the characteristics of the ideologies, and the explicit expressions. In this sense, in the field of cinema, this political perspective is not focused on looking for lines of convergence between films and a specific national culture or remote history, but between films and the ideologies that arise from the different human groups that make up societies in their immediate historical context.

From this point of view, just as there are certain films or film features that in their context can be aligned with national ideologies that favour (very often in a complex, contradictory, indirect and coded way) the interests of certain social agents, there are also films or film features that can be aligned with other ideologies that favour the interests of other social agents. For instance, just as the monumental style described by Davis was a type of aesthetics in line with the Japanese ultra-nationalism of the war, favouring the interests of the imperial regime (which was a social agent composed of multiple agents), later in the 1960s and 1970s the Japanese New Wave was a cinematographic trend aligned in broad terms with the ideology and interests of Japan's New Left movement (also a social agent composed of multiple agents, and consequently complex and sometimes contradictory). Regarding this matter, in order to carry out a political reading of the Japanese New Wave, first we have to consider the historical existence of Japan's New Left and analyse its ideology.

\section{New Left Ideology and the Formation of the Japanese New Wave}

The seed of Japan's New Left emerged in 1955. Forced by Moscow and Beijing, the Japanese Communist Party (JCP) had been sending student guerrillas to rural areas to trigger the revolution for five years, and forced again by the international communist leadership that year, it demanded that violence be renounced as a political means in order to focus on the ballot box. As a consequence, many young communists who had sacrificed their personal future in the hope of playing a part in the revolution felt betrayed by the party. However, some of those young militants did not assume the position of victims of the party, but admitted their own individual responsibility in having engaged the guerrillas. Those same young communists, influenced by important events, such as the Sunagawa Struggle (1955-57) and the Hungarian Revolution (1956), and increasingly opposed to the rigidity 
and authoritarianism of an aged JCP, in 1958 ended up creating a new political organization, the Communist League, better known as the Bund.

The Bund advocated for intensifying the subjective commitment of social movements to make the revolution happen in the short or medium term, against the JCP's 'two-stage revolution' theory, which considered that the objective factors did not allow the revolution to happen yet, and that prescribed the need to fully develop the modern structure and superstructure of the capitalist system (especially before 1950) and to get rid of the alleged situation of Japan as a United States' semi-colony (especially from 1955 onwards), before being able to implement socialism.

What is known as Japan's New Left burst onto the public scene at the end of 1959 when the Bund started heading the massive protests against the renewal of the Treaty of Mutual Cooperation and Security Japan-US, popularly known as Anpo, which reached their point of maximum confrontation in June $1960 .^{2}$ The general spirit of the protests, which was in line with that of the institutionalized left and the progressive intellectuals, was a fear that the Japanese people would become victim of a return to a 'premodern' past (related to feudalism), a totalitarian regime (related to fascism), and a new war in their own land. That is, the general spirit was defensive, aimed at protecting the so-called post-war's 'peace and democracy' system. By contrast, the New Left, in minority despite its relative leadership, had an offensive vocation: it considered that system to be a fallacy, arguing that there had never been true peace and democracy in post-war Japan, and instead of basing its action on the fear that the people would become a victim, it attacked capitalist liberal democracy as well as what it considered to be Japanese complicity with US imperialism and not submission.

For Maruyama Masao, one of the most important intellectuals of the time, the 1959-1960 struggle was a success despite the eventual renewal of Anpo, since Japanese civil society had demonstrated for the first time its great ability to mobilize outside the state. According to him, the humanistic values that progressive intellectuals had been fostering during the post-war era had made the Japanese into a more rational and modern society. Instead, Yoshimoto Takaaki, one of the few intellectuals who positioned himself in favour of the New Left (and one of the most influential in the later development of this movement), considered that modern alienation was the real driver of protests and not the ideological 'fantasies' that progressive intellectuals harboured about the progress of modernity. Both Yoshimoto and the New Left shared a strong feeling of defeat after the renewal of Anpo. ${ }^{3}$

It was from 1965 onward, after the beginning of the US bombing against Vietnam with Japan's logistical support, when the feeling of being victimizers and not victims spread among Japanese social movements. This feeling was heightened by the fact that Japan had become a powerful economic power in the world, which was also related to the profit extracted from wars within the context of the Cold War. At the same time, the memory of World War II, of fascism, and of the post-war misery was dissipating from generation to generation, so the defensive attitude based on the fear of becoming victims of the circumstances was weaker than some years ago.

The inspiring example of the Vietnamese people resisting against the greatest military power in the world, the US, imbued many Japanese activists with a spirit that superimposed subjective determination to adverse objective circumstances. However, since war did not directly harm Japanese citizens, the commitment against it was based on an exercise of subjective responsibility and awareness. At the same time, the increasing material abundance that was making the Japanese a consumer society diffused class divisions superficially, and since the ways of oppression were less direct and the enemies of the left less palpable, the focus was increasingly on alienation as a form of oppression and on individual self-transformation. More and more Japanese activists saw themselves not as victims of the

2 The term 'New Left' is used retrospectively, since it was not until 1969 that it started to be widely used by the press in Japan (Andrews 2016, p. 92). During the 1959-1960 struggle against Anpo, what we today know as the New Left was still fundamentally the Bund and also, secondary, the Japan Revolutionary Communist League (JRCL).

3 For more information about Yoshimoto's theory, see: Yasko (1997), Kelman (2001), Murakami (2005), Yang (2008), Cassegard (2008), Kersten (2009) and Noonan (2012). 
system but as members of it, sometimes in a position of power in relation to the masses, and therefore they saw the need to question their own position as subjects and to transform themselves to transform the system.

The emergence in Japanese society of such a spirit, which to some extent was already in the genes of the New Left since its seed emerged in 1955, provided this movement with a fertile field to spread its postulates. Within that context, the New Left became strongly ingrained in the movement against the Vietnam War through radical political parties and a platform that was created in 1965 under the name League for Peace in Vietnam, abbreviated as Beheiren, and in universities through the so-called Joint Struggle Committees, better known as Zenkyōtō, a set of assemblies and student organizations that organized the mass occupations and strikes on the most important campuses in Japan during 1968 and 1969.

Although we cannot refer to Japan's New Left as a monolithic or completely coherent entity, since it came to be made up of dozens of groups, and nor can we refer to it in static terms, since it underwent many changes over time, we can find in broad terms a line of ideological continuity. Generally speaking, Japan's New Left ideology was characterized by a protagonism of youth, a focus on alienation as an important form of modern oppression (the Soviet socialism model showed that alienation could also rule in a modern system despite not being strictly capitalist) that held the potential of political rebellion, a scepticism about or at least a critical look at the idea of modernity and lineal progress, an emphasis on individual self-transformation ${ }^{4}$ and on carrying it out through subjective concrete actions rather than ideological discourse from above, an ultimate responsibility of the subject over objective circumstances, and a valorization of forms of irrational behaviour (for instance resorting to violence as pure and existential political action).

The Japanese New Wave film trend developed in parallel to the development of Japan's New Left political movement. One of the biggest film production companies in Japan, Shōchiku, launched a new policy under the name of Nūberu Bāgu (the Japanese pronunciation of the French term Nouvelle Vague), through which it tried to attract younger audiences by allowing young filmmakers, such as Ōshima Nagisa, Shinoda Masahiro, and Yoshida Kijū to direct their own films. This film policy was launched in 1959, just when the struggle against Anpo was taking shape, and those new young directors were influenced by the rebellious political situation their country was going through, feeling a certain degree of affinity for the New Left as a result of the vitality and renewal the novel movement entailed. At first they tried to develop an avant-garde cinema under the tutelage and limitations that are imposed by the system of big companies, influencing other filmmakers outside Shōchiku. However, independent film production companies proliferated progressively (young avant-garde directors abandoned big film production companies just as young radical leftists had abandoned the institutional left), and from the second half of the 1960s avant-garde filmmakers started to have the freedom to make their own cinema without the dictates of the majority market, radicalizing experimentation. This process of cinematographic radicalization coincided with the parallel process of radicalization that was experienced by the political New Left movement from the beginning of the American bombings against Vietnam in 1965, and it reached its peak in the late 1960s and early 1970s with the influence of the powerful student revolts.

Just like the case of Japan's New Left, although we cannot refer to the Japanese New Wave as a monolithic or static trend, we can identify a set of general continuities. In turn, these features can be linked in broad terms with the characteristics of the New Left's ideology. I aim to illustrate this through the ideological analysis of a paradigmatic film of this trend, Eros + Massacre, and especially one of its most important sequences.

4 For more information about the New Left's notion of self-transformation see Ando (2014). 


\section{Eros + Massacre as a Reflection of Japan's New Left Ideology}

Several English works have addressed Eros + Massacre, legitimately taking into account different aspects of the film. McDonald (1983) focuses strictly on aspects of the film's content and form, and affords some cinematographic context; Desser (1988) adds a deep historical-political and broader artistic context and situates the film within the Japanese New Wave phenomenon; Yomota [2004] (2010) points to the direct connection between the political vanguard and the artistic experiment between 1968 and 1972 that produced an aesthetic unconscious particular to that era, and suggests that this is a field to be explored through a necessary grasping of the epistemological context of the film's era; Standish (2011), in turn, adds an extensive intellectual-philosophical context of the film; and, Briciu (2012) offers a reading focused on a gender perspective. What I aim to do here is to provide an ideological analysis of the film exploring the connection between the Japan's New Wave and New Left.

Although, from 1965 Yoshida produced his own films and could therefore experiment with the cinematographic medium, it was from 1968, with the filming of Eros + Massacre, that he reached full autonomy to take his experimentation to the extreme, since his works began to be screened in the cinemas of the independent film production company Art Theatre Guild (ATG) instead of the big film production companies.

The film does not have a clear axis in terms of plot. It is composed of a chaotic fragmentation of barely connected images, with a confused juxtaposition of past and present, imagination and reality. Through this deconstruction, Yoshida expresses his worldview in line with two important conceptions of Japan's New Left ideology. First, this rejection of a linear and objective narrative can be considered to be in line with the attack that the New Left made of the uncritical view of linear progress held by the old left. According to this criticism, both the JCP and the post-war progressive intellectuals had a simplistic view of Japanese history divided schematically into pre-modernity and modernity, and they considered that Japan had not yet fully entered the second stage. From this old left point of view, one of the tasks of the parties and the intelligentsia should be to modernize the masses from outside in order to develop subjectivity (shutaisei) and rationality in the Japanese. Nevertheless, the view of the most libertarian ${ }^{5}$ sectors of the New Left differed in three fundamental points: first, Japan was ready for a revolution without having to go through supposed previous stages; second, the left should consider the masses as they are and not ideally as they should be; and third, the inculcation of an ideology in the people from above limited their autonomy (jiritsu) and consequently their subjectivity. The second conception of the New Left in line with Yoshida's deconstruction is directly related to the first: the anti-discursive form that the composition adopts (in the sense that it renounces creating meaning) suggests that Yoshida rejects forcing an ideology onto the viewer from the position of the director, and that he aims to foster their subjective involvement in the film.

Although the film does not strictly have a main character, Eiko is closest to the centre of the film's complex network of dispersed interrelations. She is a young woman living at the end of the 1960s. Immersed in a state of deep alienation, she is unable to have a satisfactory sex life with other people, yet she has an insatiable desire that she only manages to calm through masturbation, which leads to her prostituting herself in her eagerness to experience an awakening of her body. It is common for Japanese New Wave films to use sexual matters as a means to juxtapose the individual with authority and its taboos, which is also in line with the New Left ideology. While films that were in line with old left ideologies often expressed the subjectivity of the main characters through romantic love, representing the spiritual bond between lovers as based on free will as opposed to premodern obligations to the nation and family, the most libertarian sectors of the New Left criticized the idealizations or 'collective fantasies' (a Yoshimoto term) made of the people, such as the idea of romantic love as a sign of

5 By 'libertarian' I mean the sectors of Japan's New Wave that most questioned authority and hierarchy and most fostered spontaneity and individuality, such as the assembly structures of Beheiren and Zenkyōtō and thinkers such as Yoshimoto Takaaki, Tanigawa Gan or Tokoro Mitsuko. 
modernity and freedom. Alienation, more than ideas, was from this point of view the driving force of individual action, containing the potential of revolutionary action. In films, this alienation could be portrayed by frustrated sex and erratic behaviour based on desires and fears more than rationality, convictions, and goals, refusing to project an image of how the characters should be. This, in addition, breaks with the sentimental empathy with the characters, thus fostering the autonomy of the viewer to reflect subjectively, in line with the autonomy that the most libertarian sectors of the New Left claimed for the masses.

Faced with her sexual impotence, Eiko seeks solutions in the history of the anarchist martyrs Ōsugi Sakae (1885-1923) and Itō Noe (1895-1923) ${ }^{6}$ and their implementation of the theory of free love. There are similarities between the ideas of these historical personalities of the Taishō era (1912-26) and the ideas of the most libertarian sectors of Japan's New Left at the end of the 1960s, since in both cases the idea prevailed that the self-transformation of people in their immediate relationships contributed to broader social transformations.

The most important sequence of the film, which lasts almost the last hour of footage, shows three totally different versions of the same historical event: that known as the Hikagejaya Incident (or Hayama Incident) of 7 November 1916, in which, according to the official history, one of Ōsugi's lovers called Kamichika Ichiko (1888-1981), whose name in the film was changed to Masaoka Ichiko, injured him with a dagger driven by jealousy towards his other lover Itō.

In the first version, Masaoka and Ōsugi are in a room and get into an argument about their love triangle. As in the whole film, many shots have a de-centered composition, in which the characters are in a minor space, often even marginal, within the set of elements of the frame. According to Burch (1979, p. 348), this is a strategy borrowed from Japanese traditional art. Burch's consideration is a good example of an ideology that is aimed at the formation of a national cinema. He finds the reason for decentralization in the cultural roots of Japan and its remote history, instead of its contemporary context. From an ideological analysis of cinema, it is more accurate to conclude that decentralization is a strategy in line with the New Left, in an anti-humanist and anti-dualist perspective that places the individual as a part of a totality of relations and not as a subject rationally confronted with the objective world. Moreover, in this type of frame the viewer is not told where to fix their attention or what compositional meaning to deduce, thus fostering their autonomy and subjectivity.

Shortly after the argument, while Ōsugi is sleeping, Masaoka stabs him. Afterwards, both of them fight throughout the house with increasingly theatrical movements. The scene's high point of theatralization occurs when the shōji (sliding paper doors) collapse one after another as Ôsugi passes through them until he lies still on the floor. In this case, a national cinema perspective could conclude that there is a direct influence of traditional Japanese theatre, while considering the anti-realistic staging. Nevertheless, although this influence may be true, it is rather indirect, mediated by the influence of the avant-garde post-Shingeki theatre of the 1960s, which used techniques that are considered premodern from kabuki, noh, and bunraku valorizing the irrational and generating a Brecthian distance between the play and the viewer fostering their autonomous reflection. From an ideological perspective of cinema, these strategies are in line with the coetaneous Japan's New Left, considering its questioning of the infallibility of the rational and the modern, and its fostering of the autonomy of the masses.

In the second version of the incident it is Ōsugi who, after stating that "revolution is nothing other than self-denial", ends up forcing Masaoka to stab him (The sentence said by Ōsugi recalls the text that appears at the end of the New Wave film of the same year Funeral Parade of Roses [Bara no Soretsu]: "The spirit of an individual reaches its own absolute through incessant negation"). It is as if,

6 Ōsugi Sakae was an anarchist known for his theory of free love, which attacked the Japanese family model and monogamy as institutions that supported private property and state power. Based on this theory, he had several lovers during his life. Itō Noe was an anarchist known for her feminist advocacy for free abortion and prostitution arguing that women are the only owners of their body, and for her call for everyday practice as a means to fight the system. Ōsugi and Itō became lovers and they were assassinated by military police in 1923 after the chaos following the Great Kantō Earthquake. 
with this self-inflicted attack, Ōsugi admitted that the renunciation of one's self and the acceptance of error (in this case error in the implementation of free love), and not the mere claiming of one's own ideas, was the only valid way of revolutionary praxis. The New Left's idea of autonomy (jiritsu), applied in the film through the aforementioned means of anti-narrativity or anti-discursivity, the focus on the alienation of the characters and the refusal of sentimental empathy, the instability of the camera and the decentralization of the frame, the theme of everyday and personal implementation of free love as a revolutionary practice, and the theatralization, is directly linked to the notion of self-denial (jiko hitei). From the most libertarian point of view of Japan's New Left, in order for the masses to have autonomy, the political subject must subjectively deny themselves, self-questioning their own position in the network of power relations, attacking oneself as a part of the ruling system in order to transform that very system, self-questioning their legitimacy and objectivity to transmit ideological messages to the people and lead it, and prioritizing direct and daily action above the discursive expression of an internal and essential self. In this sense, this stabbing scene recalls the following words of Yoshida [1969] (2010, p. 16) himself in his essay "My Film Theory. The Logic of Self-Negation" (Watashi no eigaron. Jikohitei no ronri 1969):

Our education tells us that creating is equivalent to telling or portraying something, and having been trained this way, in the process of destruction we accidentally come upon the conservative self that informs our subconscience. The weapon that I have grasped for my opposition becomes a sharp knife aimed towards the not yet awoken parts of the self. I have ended up fighting the things I turned into my own shackles.

The image of the knife against oneself is the utmost expression and symbol of self-denial, as it was the exaltation by Japan's New Left of the martyrs who sacrificed their lives during the 1960s, such as Kanba Michiko in 1960 (a student killed during the protest against Anpo), Chunoshin Yui (an Esperantist who set fire to himself in protest against the bombing of Vietnam), and Yamazaki Hiroaki (a very young student killed during a protest at the Haneda Airport against the Prime Minister Sato travelling to South Vietnam) in 1967. Also, the anarchists Ōsugi and Itō represented in Eros + Massacre were martyred when they were killed by the imperial authorities in 1923.

The idea of self-denial (related to self-transformation), with roots in the philosophy of the Kyoto School, later developed by Leftist philosophers, such as Umemoto Katsumi and Yoshimoto Takaaki, consolidated during the Vietnam War, when a lot of Japanese adopted a victimizer consciousness replacing that of the victim. This consciousness reached its peak during the student revolts between 1968 and 1970, when a lot of university students questioned their position as members of an elite, as reflected in the following words of a medical student at the University of Tokyo:

The working people who came to visit us as patients at the hospital were suffering just as much as we were as victims of the present system of medicine in Japan. Then it occurred to us, medical students and young doctors alike, that we had been victimizers rather than victims by having complacently occupied a petit bourgeois position at the expense of the people. This recognition marked a great turning point in our movement ... We finally arrived at self-criticism and self-denial, through which we clearly foresaw the possibility of alliance with the working people.

(In Tsurumi 1975, p. 215)

But beyond the influence of Japanese thinkers such as Umemoto and Yoshimoto on the shaping of the Japanese New Wave, there is also a significant influence from non-Japanese thinkers such as Herbert Marcuse and Jean-Paul Sartre, which questions the consistency of the national cinema model. Considering the advanced development of the media, the social movements in the 1960s were globally synchronic, making up a kind of 'New Left world-historical movement' (Katsiaficas 1987). This transnational synchronicity was also reflected in the world of cinema, which allows us to consider the Japanese New Wave as part of the same global phenomenon (with its specificities): what Adamson 
(2018) calls 'New Left cinema'. ${ }^{7}$ Nevertheless, it is not only the transnational factor (the fact that, for instance, Marcuse came from a German background and Sartre from a French one) what questions the national cinema model when analyzing a Japanese film, such as Eros + Massacre, but the fact that the ideas of Marcuse and Sartre (an influential figure explicitly recognized by Yoshida) contributed toward shaping the (Japan's) New Left ideology of which the New Left cinema in general and the Japanese New Wave in particular were reflections.

In the third and final version of the Hikagejaya Incident, Itō shows up at the house just at the moment when Ōsugi and Masaoka are struggling with the dagger. However, finally, it is Itō and not Masaoka who ends up stabbing Ōsugi. He lies on the floor after the stabbing, and then Itō talks to him in a low voice: "There was no other way to go beyond you. The day you passed through me like the wind, I knew freedom. But then I realized that I was captured by you, so I had to pierce through you to gain further freedom". The scene then seems to suggest that unlike Masaoka in the first version of the incident, Itō does not stab Ōsugi because of jealousy, but in order to not feel constrained by one particular man and thus achieve the true attainment of free love, as opposed to romantic love.

The three different versions of the Hikagejaya Incident are interspersed by scenes in which Eiko and a friend of hers, a man called Wada, who also suffers from sexual impotence, are in the film studio of a lover of Eiko aged about 40, called Unema, experimenting together with a camera and a projector. These interspersed scenes suggest that the three versions of the incident are, after all, imaginary creations of the events of 1916 mediated by cinema and not recreations of the facts themselves. This is in line with the most libertarian sectors of the Japan's New Left conception that history is not an object to be approached in a purely scientific way, since it is made and imagined by subjects.

At one point, Eiko dares Wada to set her on fire. He takes out a lighter with which he has been playing on several occasions during the film, and stands still holding a small flame while watching how she spreads gasoline around the room. The small flame could symbolize the alienation of the characters, which drives action with the potency of absolute action. It is in this scene, when Eiko ends up taking the lighter and setting fire to the room with both of them inside, that the potentiality of absolute action becomes absolute action, the alienation of the small flame becomes the freedom of the conflagration: through this extreme self-denial, it seems that they finally manage to have full sexual relations.

Many other Japanese New Wave films of the time end with scenes of self-destruction, such as, for instance, Ōshima's Death by Hanging (Koshikei 1968), The Man Who Put His Will on Film (Tokyo senso sengo hiwa 1970), The Ceremony (Gishiki 1971), Shinoda's Double Suicide (Shinjū: Ten no Amijima 1969), and Matsumoto's Funeral Parade of Roses (Bara no soretsu 1969). From a national cinema point of view, it could be considered that self-destructive tendencies respond to the significant role of suicide in Japanese culture. However, from an ideological perspective it is more accurate to link these tendencies with the immediate context of the Japan's New Left ideology and its notion of self-denial.

Almost at the end of Eros + Massacre, the filmmaker Unema, to whom the film studio belongs, appears in the room. He improvises a rope with the film tape, stands on a pile of film boxes, and hangs himself. Unema could be considered as the alter ego of the director of Eros + Massacre himself, Yoshida, transmitting his conception of cinema as self-denial: cinema as a discourse that denies itself.

\section{Conclusions}

In order to illustrate the political perspective of cinema in contrast to the national one, first I have rejected the use of the concept 'national' to refer directly to cinema as a set of objects in the form of films, given the fundamentally subjective and imagined (but not unreal or fabricated) nature of nation, and I have proposed to focus on the mediation of ideology (for instance, national ideologies) as a more accurate way to frame and understand cinema, linking it to the social agents of the immediate

7 For a general perspective of the different New Wave cinemas in the world, see Gerhardt and Saljoughi (2018). 
historical time when films were made and not to natural and cultural/geographical realities or remote history. This does not mean that we cannot talk, for instance, in terms of Japanese cinema, as long as we are aware that we are referring to the nationality (state) or any other objective geopolitical space (such as an autonomous region) and not the national reality (nation) of cinema (we could even talk in terms of 'Japanese national cinema' if doing so we were referring to a cinema with a specific national ideology and not a cinema that is a direct reflection of a specific nation). Nor does it mean that we cannot talk in terms of cultural or geographical influences in cinema, as long as we take into account the mediation of the immediate historical context and its socio-political agents.

Secondly, I have explored the hypothesis that the Japanese New Wave cinema of the 1960s and early 1970s is mainly a reflection of Japan's coetaneous New Left ideology, using as a validating example the concrete ideological analysis of Yoshida's film Eros + Massacre. To do so, I have first analysed the historical existence and the general ideological features of Japan's New Left, and then I have identified the lines of continuity between Eros + Massacre as a paradigmatic example of the New Wave and the broader reality of the New Left ideology, contrasting this kind of reading with what could be national cinema's interpretations. These lines of continuity can be synthetized in the concepts of self-denial (jiko hitei) and autonomy (jiritsu), which can be considered as the main differential points with respect to the ideology of the old left.

Nonetheless, this paper has an introductory purpose and it seeks to point to a methodological alternative to read the Japanese New Wave phenomenon. In future works, it could be interesting to start from this introductory line to analyse, in a more systematic and detailed manner, key New Left concepts such as self-denial and autonomy, in their relationship with cinema. Additionally, a more in-depth analysis of the ideology of the old left and the films that make up its reflection will be required, in order to contrast it with Japan's New Left and New Wave, since these later phenomena emerged as a reaction to the previous ones, and therefore they can be better understood through a deeper analysis of this confrontation. Likewise, it will be interesting to go beyond the general features of Japan's New Left ideology and focus on more specific aspects of it, such as the political philosophy of some of its most influential thinkers, and search for lines of continuity between their explicit theories and Japanese New Wave cinema.

Funding: This research received no external funding.

Acknowledgments: This chapter is based on my PhD research entitled La Nūberu Bāgu como Correlato Artístico de la Nueva Izquierda Japonesa at the PhD Program in Translation and Intercultural Studies at the Universitat Autònoma de Barcelona (UAB). My research was supported by the Research Group GREGAL (2017 SGR 1596) as a FI grant holder (AGAUR, Generalitat de Catalunya), and by the Department of Translation and Interpretation and East Asian Studies at the UAB.

Conflicts of Interest: The author declares no conflict of interest.

\section{References}

Adamson, Morgan. 2018. Enduring Images. A Future History of New Left Cinema. Minneapolis and London: University of Minnesota Press.

Adler, Fabienne. 2009. First, Abandon the World of Seeming Certainty: Theory and Practice of the "Camera-Generated Image" in Nineteen-Sixties Japan. Ph.D. thesis, Stanford University, Stanford, CA, USA, June.

Anderson, Benedict. 2006. Imagined Communities. New York: Verso. First published 1983.

Ando, Takemasa. 2014. Japan's New Left Movements. New York: Routledge.

Andrews, William. 2016. Dissenting Japan. A History of Japanese Radicalism and Counterculture from 1945 to Fukushima. London: Hurst Publishers.

Briciu, Bianca O. 2012. Negotiating Power: Gender and Body Politics in the New Wave Japanese Cinema. Ph.D. thesis, Carleton University, Ottawa, ON, Canada.

Burch, Nöel. 1979. To the Distant Observer. Form and Meaning in the Japanese Cinema. Berkeley: University of California Press. 
Cassegard, Carl. 2008. From Withdrawal to Resistance. The Rhetoric of Exit in Yoshimoto Takaaki and Karatani Kojin. The Asia-Pacific Affairs, 6.

D'Lugo, Marvin. 1991. Catalan Cinema: Historical Experience and Cinematic Practice. Quarterly Review of Film E Video 13: 131-46.

Davis, Darrell W. 1996. Picturing Japaneseness: Monumental Style, National Identity, Japanese Film. New York: Columbia University Press.

Desser, David. 1988. Eros Plus Massacre. An Introduction to the Japanese New Wave Cinema. Indianapolis: Indiana University Press.

Furuhata, Yuriko. 2013. Cinema of Actuality. Japanese Avant-Garde Filmaking in the Season of Image Politics. Durham: Duke University Press.

Gellner, Ernest. 1988. Nations and Nationalism. Oxford: Basil Blackwell. First published 1983.

Gerhardt, Christina, and Sara Saljoughi. 2018. 1968 and Global Cinema. Detroit: Wayne State University Press.

Gerow, Aaron. 2009. Narrating the Nation-ality of a Cinema: The Case of Japanese Prewar Film. In The Culture of Japanese Fascism. Edited by Alan Tansman. Durham: Duke University Press, pp. 185-211.

Higson, Andrew. 2002. The Limiting Imagination of National Cinema. In Cinema and Nation. Edited by Mette Hjort and Scott MacKenzie. New York: Routledge, pp. 63-74.

Hill, John. 1992. The Issue of National Cinema and British Film Production. In New Questions of British Cinema. Edited by Duncan Petrie. London: BFI, pp. 10-21.

Hill, John. 1996. British Film Policy. In Film Policy: International, National and Regional Perspectives. Edited by Albert Moran. London: Routledge, pp. 101-13.

Katsiaficas, George. 1987. The Imagination of the New Left. A Global Analysis of 1968. Boston: South End Press.

Kellner, Douglas. 1993. Film, Politics, and the Ideology. Toward a Multiperspectival Film Theory. In Movies and Politics. The Dynamic Relationship. Edited by James Combs. New York: Garland Publishing, pp. 55-92.

Kelman, Peter G. 2001. Protesting the National Identity: The Cultures of Protest in 1960s Japan. Ph.D. thesis, University of Sidney, Sidney, Australia, January.

Kersten, Rikki. 2009. The Intellectual Culture of Postwar Japan and the 1968-1969 University of Tokyo Struggles: Repositioning the Self in Postwar Thought. Social Science Japan Journal 12: 227-45. [CrossRef]

Ko, Mika. 2010. Japanese Cinema and Otherness. Nationalism, Multiculturalism and the Problem of Japaneseness. London: Routledge.

McDonald, Keiko. 1983. Cinema East. A Critical Study of Major Japanese Films. Teaneck: Fairleigh Dickinson University Press.

Murakami, Fuminobu. 2005. Postmodern, Feminist and Postcolonial Currents in Contemporary Japanese Culture. A Reading of Murakami Haruki, Yoshimoto Banana, Yoshimoto Takaaki and Karatani Kojin. London and New York: Routledge.

Needham, Gary. 2006. Japanese Cinema and Orientalism. In Asian Cinemas. A Reader E Guide. Edited by Dimitris Eleftheriotis and Gary Needham. Edinburgh: Edinburgh University Press, pp. 8-16.

Noonan, Patrick J. 2012. “Our Dissolution": Subjectivity, Collectivity, and the Politics of Form in 1960s Japan. Ph.D. thesis, University of California, Oakland, CA, USA.

Raine, Michael J. 2002. Youth, Body, and Subjectivity in the Japanese Cinema, 1955-60. Ph.D. thesis, The University of Iowa, Iowa City, IA, USA, May.

Ramlochand, John. 2006. Japanese Cinema: Time, Space, Nation. Ph.D. thesis, McGill University, Montréal, QC, Canada, May.

Standish, Isolde. 2011. Politics, Porn and Protest. Japanese Avant-Garde Cinema in the 1960s and 1970s. New York: The Continuum International Publishing Group.

Tsurumi, Kazuko. 1975. Student Movements in 1960 and 1969. Continuity and Change. In Postwar Trends in Japan. Edited by Shunichi Takayanagi and Kimitada Miwa. Tokyo: University of Tokyo Press, pp. 195-227.

Yang, Manuel. 2008. Yoshimoto Taka'aki's Karl Marx: Translation and Commentary. Ph.D. thesis, University of Toledo, Toledo, OH, USA, August.

Yasko, Guy T. 1997. The Japanese Student Movement 1968-70: The Zenkyoto Uprising. Ph.D. thesis, Cornell University, Ithaca, NY, USA, August.

Yomota, Inuhiko. 2010. The Genealogy of the Mother. Eros plus Massacre. In Yoshida Kijū: 50 Years of Avant-Garde Filmaking in Postwar Japan. Edited by Dick Stegewerns. Oslo: Norwegian Film Institute, pp. 42-51. First published 2004. 
Yoshida, Kijū. 2010. My Film Theory. The Logic of Self-Negation. In Yoshida Kijū: 50 Years of Avant-Garde Filmaking in Postwar Japan. Edited by Dick Stegewerns. Oslo: Norwegian Film Institute, pp. 15-18. First published 1969. Žižek, Slavoj. 1994. Mapping Ideology. London and New York: Verso.

(c)

(C) 2018 by the author. Licensee MDPI, Basel, Switzerland. This article is an open access article distributed under the terms and conditions of the Creative Commons Attribution (CC BY) license (http:/ / creativecommons.org/licenses/by/4.0/). 